\title{
FATHOM
}

\section{Introduction: Human, All Too Human}

Introduction: Humain, trop humain

\section{Marie Panter and Laurence Estanove}

\section{(2) OpenEdition}

\section{Journals}

Electronic version

URL: http://journals.openedition.org/fathom/617

DOI: 10.4000/fathom.617

ISSN: 2270-6798

\section{Publisher}

Association française sur les études sur Thomas Hardy

\section{Electronic reference}

Marie Panter and Laurence Estanove, «Introduction: Human, All Too Human », FATHOM [Online] 4 | 2016, Online since 15 October 2016, connection on 20 April 2019. URL : http:// journals.openedition.org/fathom/617; DOI : 10.4000/fathom.617

This text was automatically generated on 20 April 2019. 


\title{
Introduction: Human, All Too Human
}

\author{
Introduction: Humain, trop humain
}

Marie Panter and Laurence Estanove

"Humanity Appears upon the Scene, Hand in Hand with Trouble"

(The Return of the Native, I-ii)

1 Hardy's loss of faith and discovery of evolutionism has had significant impact on his work, which has been analysed thoroughly from this viewpoint ${ }^{1}$. His late novels in particular take place in a faithless and harsh universe, and the destiny of his most famous characters can be convincingly read as a never-ending struggle for life. And yet, let us recall Hardy's most famous statement about that seemingly growing pessimism:

My pessimism - if pessimism it be - does not involve the assumption that the world

is going to the dogs... On the contrary, my practical philosophy is distinctly meliorist. What are my books but one plea against "man's inhumanity to man", woman, and to the lower animals?... Whatever may be the inherent good or evil in life, it is certain that men make it much worse that it need be... (Archer 35-36)

Hardy points at "man's inhumanity" as his work's main concern, inviting us to read his books as a fierce denunciation of it. Pessimism could thus be understood as the reverse side of a strong idealism. Though disillusioned and disappointed by his contemporaries, Hardy never gave up reflecting on what could be "man's humanity"; this is what inspired the choice of this issue's perspective. Our Nietzschean title reflects both Hardy's darkly pessimistic view of the world as it is, and his sincere call for a world as it could be humane and altruistic. The references to Nietzsche and altruism are thus not incidental, but based on Hardy's strong engagement with the Victorian intellectual and ideological context.

2 Thomas Hardy's life and career occurred in an era of major disruptions and advances in the knowledge of man and in the understanding of his place in the universe. Hardy contributed effectively to the debates of the Victorian period, and responded both as novelist and as poet to the great unsettling questions of his contemporaries in the wake 
of the appearance of evolutionism but also of the advent of life sciences and of the birth of social sciences. His knowledge of mankind stands at the confluence of old traditions and radically new paradigms. His long life and career allowed him to witness a great array of epistemological changes, yet this only partly explains the depth and complexity of the reflexions on man offered by his writings. Hardy was an attentive reader of Mill, Arnold, Huxley, Spencer, but also of Taine, Renan, or naturally Comte. His works thus bears the obvious trace of his erudition on the theoretical constructs of his time, while informing a very distinctive, idiosyncratic knowledge of a literary non-didactic nature. One is accordingly led to consider this knowledge, following Pierre Macherey's perspective, as "thought without concepts, thought which does not communicate through the construction of speculative systems whereby the search for truth is assimilated to a line of argumentative demonstration" (Macherey 198; translation ours). Indeed, from the writings of his time Hardy seems to have extracted tools for the examination of human life - always refusing, though, to adhere to any determined school of thought.

From evolutionism, astronomy or geology, Hardy learnt the necessary humility of the human condition. Exploring all forms of beings, living or inanimate, he lingers on the inbetween position of the human scale to study its rules and customs with the eye of a social scientist. Despite its pessimistic reputation, Hardy's work investigates the whole of that "strained, hard-run Humanity" ("In Death Divided", Satires of Circumstance [1914], Hardy 321) with acute perceptiveness and extended compassion. Forcing man to accept the ordinariness of his place in the universe does not bound his condition so much as it hands over to him the entire responsibility of historical destiny and of the advent of another humanity. Hardy thus appears as a true observer of human life, as well as a genuine humanist.

The present issue therefore seeks to explore humanity as a theme (dealt with through the questions of animal suffering, the individual and the psyche, posthumanism, identity and the unconscious, etc.), but also to reveal the poetical implications (both in verse and fiction) of this prime question in Hardy's writing. What emerges eventually from this collection of essays is Hardy's deep concern with ethics and the sheer necessity to read his work as an ethical questioning.

\section{BIBLIOGRAPHY}

Archer, William, "Real Conversations: Conversation II. - With Mr Thomas Hardy", Pall Mall Magazine 23 (April 1901, 527-537), Thomas Hardy Remembered, ed. Martin Ray, Aldershot: Ashgate, 2007, 28-37.

Hardy, Thomas, The Complete Poems, ed. James Gibson, Basingstoke: Palgrave, 2001.

Macherey, Pierre, A quoi pense la littérature ?, Paris: PUF, 1990. 


\section{NOTES}

1. See for instance Gillian Beer, Darwin's Plots: Evolution in Darwin, George Eliot and NineteenthCentury Fiction, Cambridge: CUP, 2000, and in France, "Variations on Darwin", eds. Laurence Talairach-Vielmas \& Catherine Lanone, Miranda [online] 1 (2010) <http://miranda.revues.org/321 $>$ (last accessed 8 Oct 2016). 